\title{
NAGYSZILÁRDSÁGÚ ACÉLOK ELEKTRONSUGARAS HEGESZTETT KÖTÉSEINEK FÁRADÁSOS REPEDÉSTERJEDÉSSEL SZEMBENI ELLENÁLLÁSA
}

\author{
Sisodia, $\mathbf{R}$. \\ PhD hallgató, Miskolci Egyetem, Anyagszerkezettani és Anyagtechnológiai Intézet \\ 3515 Miskolc, Miskolc-Egyetemváros, e-mail: metraghu@uni-miskolc.hu \\ Gáspár, M. \\ egyetemi docens, Miskolci Egyetem, Anyagszerkezettani és Anyagtechnológiai Intézet \\ 3515 Miskolc, Miskolc-Egyetemváros, e-mail: metraghu@uni-miskolc.hu
}

\begin{abstract}
Absztrakt
A kutatómunka az S960QL nemesitett és az S960M termomechanikusan kezelt nagyszilárdságú szerkezeti acélok elektronsugaras hegesztett kötéseinek fáradásos repedésterjedéssel szembeni ellenállására irányult. A hegesztési kísérletek során $15 \mathrm{~mm}$ vastag alapanyagokat alkalmaztunk hozaganyag nélküli (autogén), I-varratos, hegesztett kötések létrehozásához. A repedésterjedési vizsgálatokhoz alkalmazott hárompontos hajlitó (TPB) próbatesteket úgy munkáltuk ki, hogy azok a jellemzö irányokra merölegesek, illetve párhuzamosak legyenek, valamint a bemetszések helyzetét a hegesztett kötések jellemzö részeinek (varrat, beolvadási vonal, höhatásövezet) elemzése céljából is változtattuk. Ennek megfelelöen a vizsgálataink során terjedö repedések a valós szerkezetekben elöforduló, különbözö repedés megjelenési helyeknek felelnek meg. A vizsgált S960M acél elektronsugaras hegesztett kötésének färadásos repedésterjedéssel szembeni ellenállása a vizsgált irányokban szignifikánsan különbözönek bizonyult, az S960QL acél esetében ilyen különbség nem mutatkozott. A vizsgált S960QL acél elektronsugaras hegesztett kötései, mindkét vizsgált irányban lényegesen érzékenyebbeknek bizonyultak a fáradással terjedö repedések elhelyezkedésére, mint a vizsgált S960M acél kötései.
\end{abstract}

Kulcsszavak: nagyszilárdságú acél, elektronsugaras hegesztés, nemesitett, termomechanikusan kezelt, fáradásos repedésterjedés

\begin{abstract}
The research focused on the fatigue crack growth resistance of electron beam welded joints of quenched and tempered S960QL and termomechanically rolled S960M high strength structural steels. In the welding experiments, $15 \mathrm{~mm}$ thick base materials were used to prepare the autogenous welded joints with I weld geometry. The three-point bending (TPB) specimens used for the fatgure crack growth tests were designed to be perpendicular or parallel to the characteristic directions, and the notch positions were also changed for the analysis of the characteristic parts of the welded joints (weld, fusion line, heat-affected zone). The cracks propagating during our tests correspond to the different crack appearances in the real welded structures. The fatigue crack growth resistance of the electron beam welded joint of the examined S960M steel proved to be significantly different in the examined directions, the $S 960 Q L$ steel did not show such a difference. The electron beam welded joints of S960QL steel proved to be significantly more sensitive to the location of fatigue cracking cracks in both directions than the joints of the examined S960M steel.
\end{abstract}

Keywords: high strength steel, electron beam welding, quenched and tempered, thermomechanically rolled, fatigue crack growth 


\section{Bevezetés}

A jármüiparban egyre nagyobb igény mutatkozik a nagyszilárdságú szerkezeti acélok alkalmazására, amelyekkel jelentős sajáttömeg csökkenést lehet elérni a mérnöki szerkezetekben. Ezeket a szerkezeti acélokat rendszerint nemesítéssel vagy termomechanikus kezeléssel állítják elő, amely hőkezelési és hengerlési technológiáknak köszönhetően a nagyszilárdságú acélok a kimagasló szilárdsági jellemzők mellett jelentős szívóssággal is rendelkeznek. Hegesztett szerkezetek esetén ezen acéloknak az alkalmazása azonban számos kihívást tartogat a felhasználók számára. A nagyszilárdságú acélok rendkívül érzékenyek a hegesztési höbevitelre, amelynek hatására a mechanikai tulajdonságok romlása következik be a hőhatásövezetben [1]. További nehézséget jelent, hogy a nagyobb szilárdsági kategóriák esetén korlátozott hozaganyag választék áll rendelkezésre, $1100 \mathrm{MPa}$ folyáshatár felett pedig nincsenek is az alapanyaggal azonos szilárdsági jellemzőket biztosító, ún. matching típusú hozaganyagok. Az ipari gyakorlatban az ömlesztő hegesztő eljárások közül alapvetően a huzalelektródás védőgázos ívhegesztést alkalmazzák a leggyakrabban. Ez a technológia egyrészt viszonylag nagy hőbevitellel jár, másrészt pedig csak hozaganyagos változatban érhető el, ebből következően igény van a kis hőbevitelt eredményező, ugyanakkor termelékeny hegesztő eljárások alkalmazására. A nagy hőáramsürüségü hegesztő eljárások (elektronsugaras és lézersugaras hegesztés) egyedülálló lehetőséget biztosítanak ezen acélok hegesztésére, mivel a kulcslyuk technológiának köszönhetően keskeny hőhatásövezettel rendelkező mély varratok állíthatók elő. Ebből adódóan a mechanikai tulajdonságok romlása egy szükebb anyagtérfogatra koncentrálódik, mint ívhegesztések esetén [2].

A nagyszilárdságú acélok széleskörü felhasználását az is nehezíti, hogy a nagy szilárdságból származó előnyök elsősorban a szerkezetek statikus terhelése esetén használhatók ki. Ugyanakkor a nagyszilárdságú acélból készülő, sok esetben mozgó hegesztett szerkezetek vagy szerkezeti elemek gyakran ismétlődő igénybevételnek vannak kitéve. Statisztikai adatok azt mutatják, hogy a tönkremenetelek harmada a hegesztett kötésekben jelentkezik, míg négyötödük ismétlődő igénybevételü szerkezetekben következik be. Továbbá, az esetleges kötéshibák, anyagfolytonossági hibák kiemelt kockázatot jelentenek az ismétlődő igénybevételü terhelések esetében [3]. Hegesztett szerkezetek esetén kérdésként fogalmazódik meg a felhasználók számára, hogy a hegesztett kötések fáradással szembeni ellenállása milyen viszonyban van az alapanyag(ok) fáradási tulajdonságaival, továbbá sok esetben az alkalmazott hegesztéstechnológia szerepe is kritikusnak bizonyul a hegesztett kötés ismétlödő igénybevétellel szembeni ellenállásában. Számos kutatás foglalkozik a hozaganyag-alapanyag szilárdsági és alakváltozási viszonyának (matching kérdéskör), valamint a hegesztési hőbevitelnek fáradási tulajdonságokra gyakorolt hatásával $[1,4,5]$.

A kísérleteinkhez hozaganyag nélküli (autogén) elektronsugaras hegesztést alkalmaztunk az S960QL nemesített és az S960M termomechanikusan kezelt szerkezeti acélok hegesztett kötéseinek elkészítéséhez. A hegesztett kötések ismétlődő igénybevétellel szembeni ellenállását, a nagyszilárdságú acélokra jellemző fokozott repedési veszélyre való tekintettel, fáradásos repedésterjedési sebesség vizsgálatok elvégzésével elemeztük, amelyek során statisztikai szemlélet követtünk mind a kísérletek tervezése, mind azok eredményeinek kiértékelése során. Ez lehetővé tette a kapott eredmények érvényességi tartományának kiszélesítését és az adatok megbízhatóságának növelését.

\section{A nagyszilárdságú acélok hegeszthetősége}

A nemesített nagyszilárdságú szerkezeti acélok hegesztésekor a viszonylag nagy karbonegyenérték miatt a Graville diagram alapján fokozott hidegrepedési hajlammal kell számolni mind a varrat, mind pedig a hőhatásövezet esetén. Ebből adódóan hegesztésükhöz előmelegítés javasolt, valamint töreked- 
ni kell a varratban lévő diffúzióképesség hidrogéntartalom csökkentésére. A repedési veszély mellett problémaként jelentkezik a varratban és a hőhatásövezetben bekövetkező szívósságcsökkenés, amelynek oka részben a hegesztés során kialakuló martenzites, illetve a hülési idő függvényében felsőbénites szövetszerkezetre, a hőhatásövezetben végbemenő szemcsedurvulásra és a martenzit-ausztenit (M-A) szigetek kialakulására vezethető vissza. Túlságosan nagy hegesztési hőbevitel esetén a hőhatásövezetben kilágyult részek is kialakulhatnak, amelyek csökkentik a hegesztett kötés teherviselö képességét [1].

Az előzőekben ismertetett okok miatt a hegesztéstechnológia tervezéséhez alkalmazott t $8 / 5$ hülési idő a hidegrepedésképződési hajlam miatt alulról, a szívósság- és a szilárdságcsökkenés miatt pedig felülről is korlátos. Az S960QL acél huzalelektródás védőgázos ívhegesztése esetén általában 5-10 s szokott lenni ez az ajánlott hülési időtartomány. Termomechanikusan kezelt nagyszilárdságú acélok esetén a kisebb karbontartalom és karbonegyenérték miatt előmelegítést a vékony és a középvastag lemezek esetén nem szükséges alkalmazni, valamint a szívósságcsökkenés mértéke is kisebb. Ebből következően az ajánlott $t_{8 / 5}$ hülési időtartomány a nemesített nagyszilárdságú acélokhoz képest széle$\operatorname{sebb}(3-15 \mathrm{~s})[1,4]$.

Elektronsugaras hegesztés esetén a nagy höáramsürüség miatt a t8/5 hülési idő értéke általában $5 \mathrm{~s}$ alatt van, amely kedvező a mechanikai tulajdonságok megőrzése szempontjából, a hidegrepedések elkerülésében pedig a védelemként alkalmazott nagy vákuum nyújt biztosítékot a varrat diffúzióképes hidrogéntartalmának csökkentésére.

\section{Kísérletek}

\subsection{Vizsgált anyagok}

A vizsgálatainkhoz S960QL nemesített és S960M termomechanikusan kezelt nagyszilárdságú szerkezeti acélokat alkalmaztunk, $15 \mathrm{~mm}$-es lemezvastagsággal. Az alapanyagok, valamint a füzéshez használt 1,2 mm átmérőjü, az MSZ EN ISO 16834-A szabvány szerinti G 895 M21 Mn4Ni2,5CrMo jelölésü, „matching típusú”, Union X96 huzalelektróda vegyi összetételét az 1. táblázat, mechanikai tulajdonságait a 2. táblázat tartalmazza.

1. táblázat. A vizsgált alapanyagok és a füzéshez használt hozaganyag mechanikai jellemzöi

\begin{tabular}{|l|c|c|c|c|}
\hline \multicolumn{1}{|c|}{ Jelölés } & $\mathbf{R}_{\mathbf{p 0 , 2}, \mathbf{M P a}}$ & $\mathbf{R}_{\mathbf{m}}, \mathbf{M P a}$ & $\mathbf{A}_{\mathbf{5}}, \mathbf{\%}$ & $\mathbf{K V}_{-\mathbf{4 0}}{ }^{\circ} \mathbf{C}, \mathbf{J}$ \\
\hline S960QL & 1014 & 1053 & 14 & 75 \\
\hline S960M & 1051 & 1058 & 17 & 177 \\
\hline X96 & $\geq 930$ & $\geq 980$ & $\geq 14$ & $\geq 40$ \\
\hline
\end{tabular}

Megfigyelhető, hogy az S960M acél esetén a termomechanikus kezelésnek köszönhetően közelítőleg fele akkora karbontartalom esetén érik el ugyanazt a szilárdságot, mint az S960QL acélnál.

2. táblázat. A vizsgálat alapanyagok és hozaganyagok vegyi összetétele, tömeg\%-ban

\begin{tabular}{|l|c|c|c|c|c|c|c|c|c|c|c|c|}
\hline Jelölés & $\mathbf{C}$ & $\mathbf{S i}$ & $\mathbf{M n}$ & $\mathbf{C r}$ & $\mathbf{M o}$ & $\mathbf{N i}$ & $\mathbf{S}$ & $\mathbf{P}$ & $\mathbf{T i}$ & $\mathbf{V}$ & $\mathbf{C u}$ & $\mathbf{A l}$ \\
\hline S960QL & 0,17 & 0,23 & 1,23 & 0,20 & 0,588 & 0,04 & 0,001 & 0,011 & 0,00 & 0,04 & 0,01 & 0,06 \\
\hline S960M & 0,09 & 0,32 & 1,63 & 0,59 & 0,29 & 0,03 & 0,001 & 0,011 & 0,02 & - & - & 0,04 \\
\hline X96 & 0,12 & 0,80 & 1,90 & 0,45 & 0,55 & 2,35 & - & - & - & - & - & - \\
\hline
\end{tabular}




\subsection{Kísérleti körülmények}

A hegesztési kísérletek során $300 \times 150 \times 15 \mathrm{~mm}$ lemezek tompahegesztését végeztük el, a lemezek éleinek leélezése nélkül, I varratkialakítással. A kedvezőbb varrattulajdonságok elérése érdekében ugyanebből az anyagminőségből alátétlemezt alkalmaztunk $300 \times 50 \times 15 \mathrm{~mm}$ méretben gyökmegtámasztás céljából. Előzetes hegesztési kísérletek alapján sikerült meghatározni a teljes átolvadást eredményező optimális elektronsugaras hegesztési paramétereket, amelyek a 3. táblázatban szerepelnek. A munkatávolság $500 \mathrm{~mm}$ volt. A hegesztést egy rétegben, előmelegítés nélkül végeztük el az 1 . ábrán látható készülékben egy EBOCAM EK74C - EG150-30BJ típusú elektronsugaras berendezéssel teljes vákuum alkalmazása $\left(2 \times 10^{-4}\right.$ mbar $)$ mellett. A hegesztést követően a munkadarabot néhány percen keresztül hagytuk lehülni a vákuumkamrában az oxidáció elkerülése érdekében.

\section{3. táblázat. Az alkalmazott hegesztési paraméterek}

\begin{tabular}{|c|c|c|c|c|c|}
\hline $\mathbf{U}_{\mathbf{g y}}, \mathbf{k V}$ & $\mathbf{I}_{\mathbf{s}}, \mathbf{m A}$ & $\mathbf{V}_{\mathbf{h}}, \mathbf{m m} / \mathbf{s}$ & $\mathbf{d}_{\mathbf{s}}, \mathbf{m m}$ & $\mathbf{I}_{\mathbf{f}}, \mathbf{m A}$ & $\mathbf{p}, \mathbf{m b a r}$ \\
\hline 150 & 49 & 10 & 0,4 & 2067 & $2 \times 10^{-4}$ \\
\hline
\end{tabular}
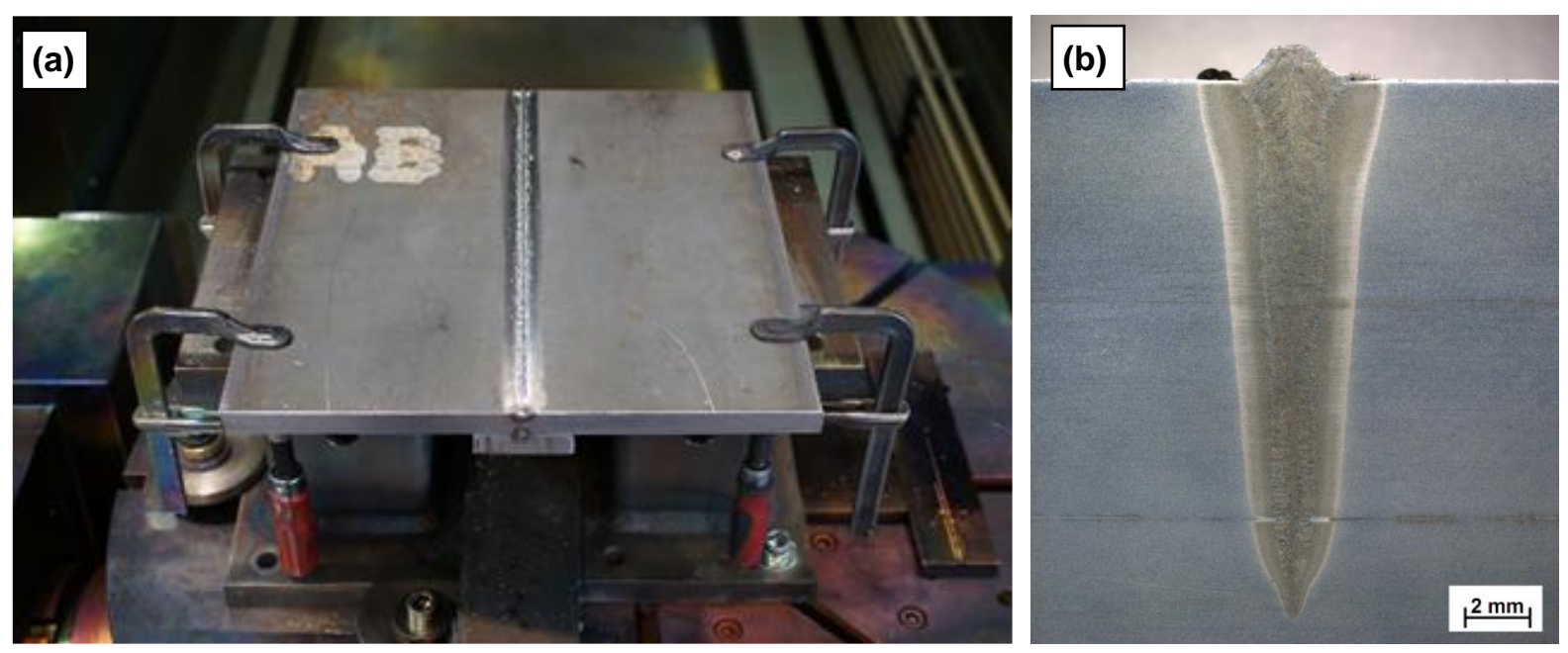

1. ábra. A készülékben elhelyezett hegesztett kötés (a) és annak makrocsiszolata (b)

A fáradásos repedésterjedési sebesség vizsgálatokhoz a hegesztett kötésekből hárompontos hajlító TPB (three point bend) próbatesteket munkáltunk ki, amelyek méreteit az 5. és a 6. táblázatok tartalmazzák. A próbatestek orientációjának jelölésében T: a legkisebb nyújtás iránya, L: a legnagyobb nyújtás iránya, S: a legnagyobb zömítés iránya; első karakter: a repedés síkjára merőleges irány, második karakter: a törés várható iránya (2. ábra (b) részlet). A próbatestek vázlatát és a bemetszések elhelyezkedését a 2. ábra szemlélteti. A hegesztett kötés irányainak jelöléseit használva $21(21 \mathrm{~W})$ és $23(23 \mathrm{~W})$ irányban munkáltuk ki a próbatesteket. Annak érdekében, hogy a bemetszések elhelyezkedése minél inkább reprezentálja a valós szerkezetekben előforduló legjelentősebb és legveszélyesebb repedéseket, a varrat középvonalához képest különböző távolságokra munkáltuk ki a bemetszéseket, mindkét irányon belül.

Az FCG vizsgálatok esetében húzó igénybevételt alkalmaztunk, $R=0,1$ terhelés aszimmetria tényezővel, szinusz alakú terhelésfüggvénnyel, szobahőmérsékleten, laboratóriumi körülmények között, 
MTS gyártmányú elektrohidraulikus anyagvizsgáló berendezéssel. A terhelési frekvencia a vizsgálatok során változott, a repedésterjedés kétharmad részéig $\mathrm{f}=20 \mathrm{~Hz}$ frekvenciát alkalmaztunk, az utolsó harmadban pedig $\mathrm{f}=5 \mathrm{~Hz}$ frekvenciát. A terjedő repedést optikai módszerrel követtük, videokamera segítségével, 100x-os nagyítás mellett [2].

(a)

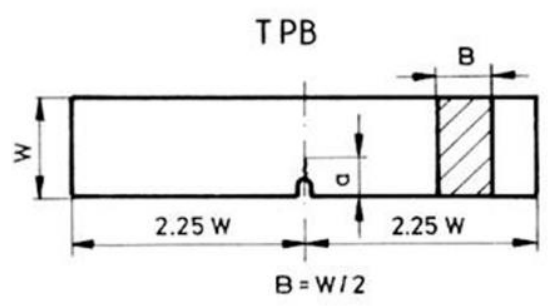

(b)

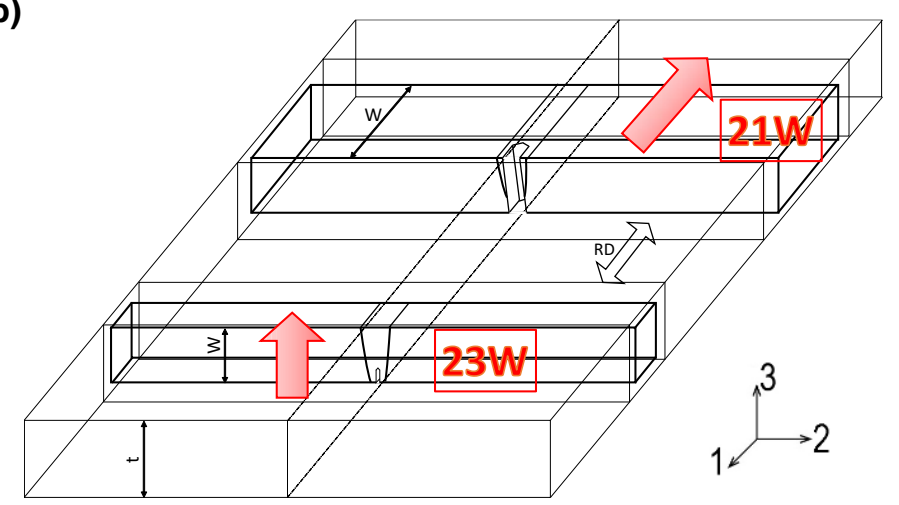

2. ábra. A kimunkált TPB próbatestek geometriája (a) és elhelyezkedése (b) a hegesztett kötésben

\section{Eredmények és következtetések}

Az eredmények kiértékeléséhez az ASTM által kiadott [7] szabványt alkalmaztuk, amely a fáradásos repedésterjedéses vizsgálatok végrehajtására és értékelésére vonatkozik. A fáradásos repedésterjedési sebesség vizsgálatokat legjobban jellemző Paris-Erdogan összefüggés (1) konstansainak ( $C$ és $n)$ meghatározását a legkisebb négyzetek módszerével végeztük [8]. Minden egyes kísérlet esetében meghatároztuk a feszültségintenzitási tényező tartománya $(\Delta K)$ és a fáradásos repedésterjedési sebesség $(d a / d N)$ értékpárokat.

$$
\frac{d a}{d N}=C(\Delta K)^{n}
$$

A T-L/21W orientációra vonatkoztatva a két anyagminőség esetén a repedésméret-igénybevételi szám görbék a 3. ábrán, a kinetikai diagramok pedig a 4. ábrán láthatók. A Paris-Erdogan összefüggés elektronsugaras hegesztett kötések különböző részeire meghatározott konstansainak értékeit az S960QL esetében az 5., az S960M acél esetében a 6. táblázat tartalmazza. A táblázatok adataiból (elsősorban az n értékekből) látható a vizsgált hegesztett kötések különböző részeinek (varrat, összeolvadási vonal, hőhatásövezet) eltérő viselkedése ismétlődő igénybevétel esetén, valamint a vizsgált szilárdsági kategóriánál az eltérő alapanyag gyártástechnológia fáradásos repedésterjedéssel szembeni ellenállásra gyakorolt hatása. A vizsgálataink során kapott eredmények és azok kiértékelése alapján lehetőség nyílik fáradásos repedésterjedési határdiagramok meghatározására $[9,10]$. 


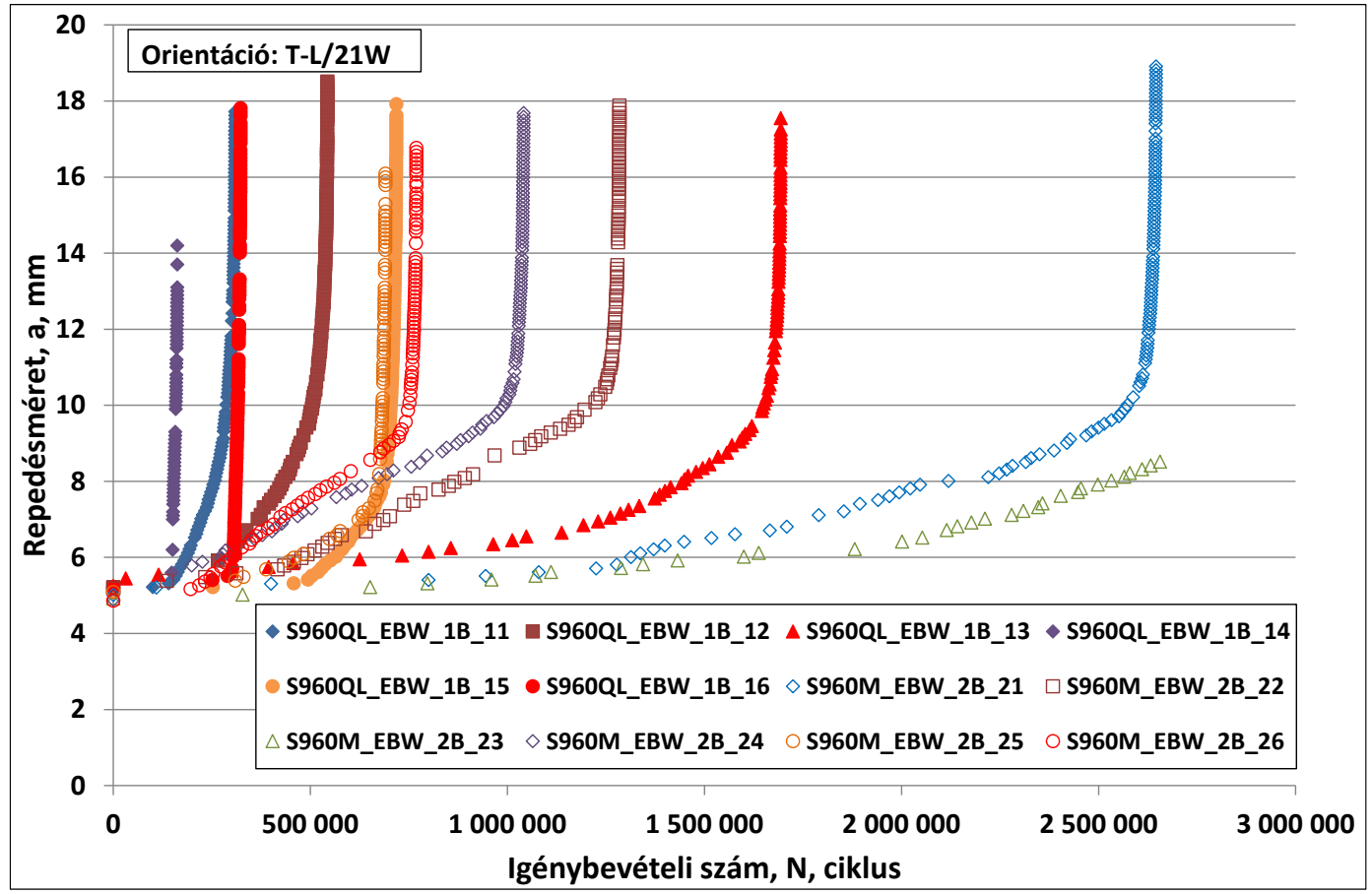

3. ábra. A repedésterjedési sebesség vizsgálatok repedésméret-igénybevételi szám görbéi $T-L / 21 \mathrm{~W}$ orientáció esetén

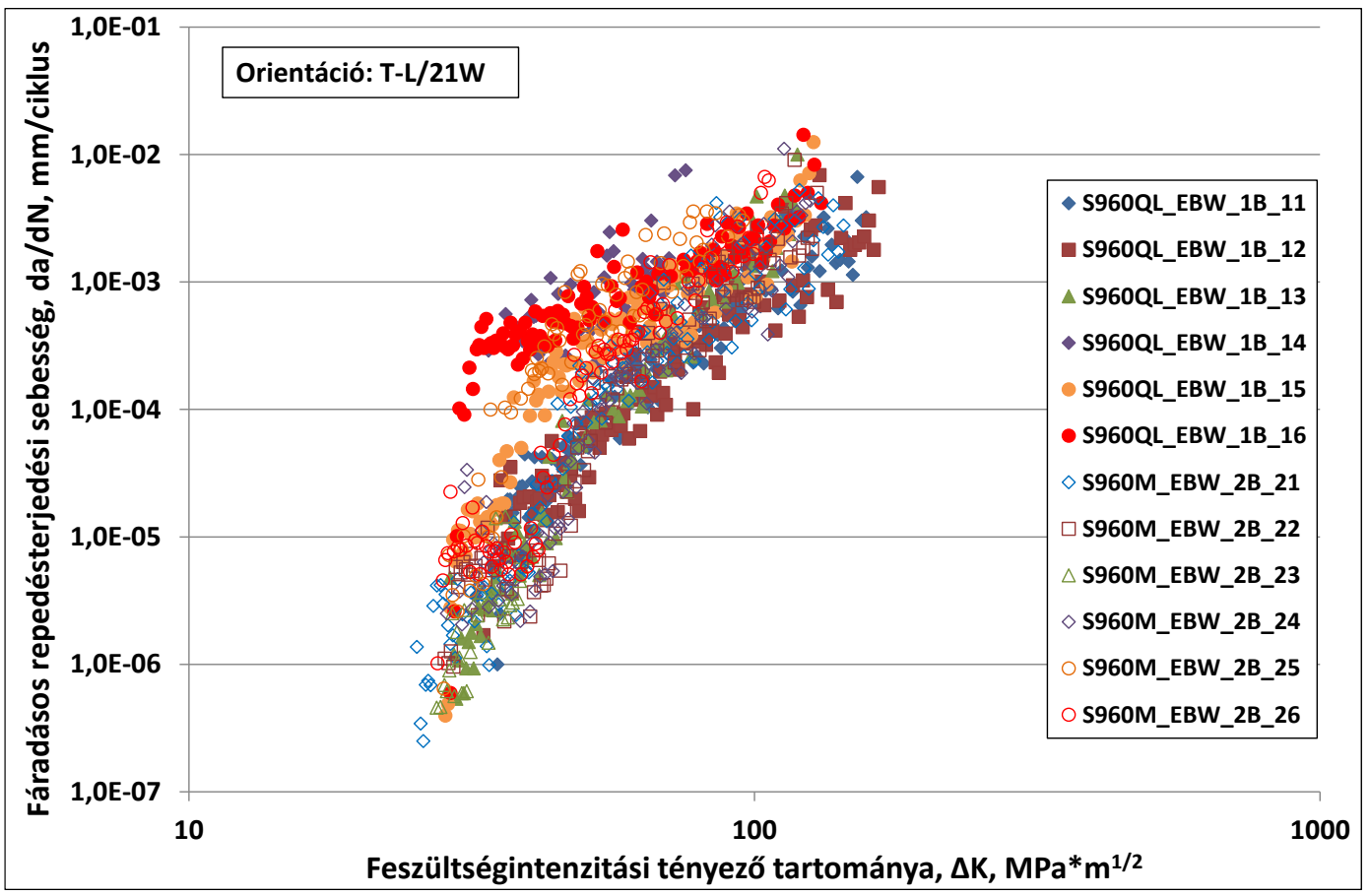

4. ábra. A fáradásos repedésterjedési sebesség vizsgálatok kinetikai diagramjai $T-L / 21 \mathrm{~W}$ orientáció esetén 
5. táblázat. A fáradási repedésterjedési vizsgálatok eredményei az $S 960 Q L$ acél esetén

\begin{tabular}{|c|c|c|c|c|c|c|c|}
\hline \multirow[t]{2}{*}{ Próbatest } & \multirow{2}{*}{$\frac{\mathbf{W}}{\mathbf{m m}}$} & \multirow{2}{*}{$\frac{\mathrm{B}}{\mathrm{mm}}$} & \multirow{2}{*}{$\frac{\mathbf{a}_{0}}{\mathbf{m m}}$} & \multirow{2}{*}{$\begin{array}{l}\text { Repedés } \\
\text { útja }\end{array}$} & \multirow{2}{*}{\multicolumn{2}{|c|}{\begin{tabular}{c|c}
$\mathrm{n}$ & $\mathrm{C}$ \\
$\mathrm{mm} /$ ciklus, MPam $^{1 / 2}$ \\
\end{tabular}}} & \multirow{2}{*}{$\begin{array}{c}\begin{array}{c}\text { Korrelációs } \\
\text { együttható }\end{array} \\
- \\
\end{array}$} \\
\hline & & & & & & & \\
\hline \multicolumn{8}{|c|}{ Próbatest elhelyezkedése: T-S/23W } \\
\hline $1 \mathrm{~S} \_11$ & 12,96 & 6,55 & 3,51 & $\mathrm{~V}$ & 3,481 & $7,411 \mathrm{E}-11$ & 0,9716 \\
\hline $1 \mathrm{~S} \_12$ & 12,97 & 6,56 & 3,54 & $\mathrm{~V}$ & 2,468 & $1,502 \mathrm{E}-08$ & 0,9508 \\
\hline $1 \mathrm{~S} \_13$ & 12,95 & 6,56 & 3,58 & ÖV & 3,061 & 1,014E-09 & 0,9675 \\
\hline $1 \mathrm{~S} \_14$ & 12,98 & 6,55 & 3,52 & ÖV & 1,977 & $1,534 \mathrm{E}-07$ & 0,9198 \\
\hline $1 \mathrm{~S} \_15$ & 12,96 & 6,54 & 3,54 & HHÖ & 3,071 & $1,236 \mathrm{E}-09$ & 0,9599 \\
\hline $1 \mathrm{~S} \_16$ & 12,96 & 6,53 & 3,61 & HHÖ & 1,330 & $2,870 \mathrm{E}-06$ & 0,8347 \\
\hline \multicolumn{8}{|c|}{ Próbatest elhelyezkedése: T-L/21W } \\
\hline 1B_11 & 25,90 & 12,87 & 5,12 & $\mathrm{~V}$ & 3,649 & $3,976 \mathrm{E}-11$ & 0,9574 \\
\hline 1B_12 & 25,93 & 12,87 & 5,22 & $\mathrm{~V}$ & 3,866 & $1,292 \mathrm{E}-11$ & 0,9468 \\
\hline 1B_13 & 25,92 & 12,87 & 5,25 & ÖV & 5,791 & $6,381 \mathrm{E}-15$ & 0,9665 \\
\hline 1B_14 & 25,85 & 12,87 & 5,20 & ÖV & 2,631 & $2,184 \mathrm{E}-08$ & 0,7083 \\
\hline 1B_15 & 25,92 & 12,87 & 5,12 & HHÖ & 3,993 & $2,553 \mathrm{E}-11$ & 0,9293 \\
\hline 1B_16 & 25,84 & 12,87 & 5,21 & HHÖ & 2,062 & 1,897E-07 & 0,9245 \\
\hline
\end{tabular}

6. táblázat. A fáradási repedésterjedési vizsgálatok eredményei az S960M acél esetén

\begin{tabular}{|c|c|c|c|c|c|c|c|}
\hline \multirow[t]{2}{*}{ Próbatest } & $\mathbf{W}$ & B & $\mathbf{a}_{0}$ & \multirow{2}{*}{$\begin{array}{c}\text { Repedés } \\
\text { útja }\end{array}$} & $\mathbf{n}$ & $\mathbf{C}$ & \multirow{2}{*}{$\begin{array}{c}\begin{array}{c}\text { Korrelációs } \\
\text { együttható }\end{array} \\
-\end{array}$} \\
\hline & $\mathbf{m m}$ & $\mathbf{m m}$ & $\mathbf{m m}$ & & \multicolumn{2}{|c|}{ mm/ciklus, MPam ${ }^{1 / 2}$} & \\
\hline \multicolumn{8}{|c|}{ Próbatest elhelyezkedése: T-S/23W } \\
\hline $2 \mathrm{~S} \_21$ & 12,98 & 6,56 & 3,90 & $\mathrm{~V}$ & 3,149 & $6,165 \mathrm{E}-10$ & 0,9363 \\
\hline $2 \mathrm{~S} \_22$ & 12,98 & 6,56 & 3,94 & $\mathrm{~V}$ & 3,131 & $7,767 \mathrm{E}-10$ & 0,9294 \\
\hline $2 S \_23$ & 12,95 & 6,56 & 3,93 & ÖV & 3,814 & $4,408 \mathrm{E}-11$ & 0,9557 \\
\hline $2 \mathrm{~S} \_24$ & 12,94 & 6,56 & 3,93 & ÖV & 3,704 & $4,833 \mathrm{E}-11$ & 0,9479 \\
\hline $2 \mathrm{~S} \_25$ & 12,97 & 6,56 & 3,96 & HHÖ & 4,021 & $1,424 \mathrm{E}-11$ & 0,9653 \\
\hline $2 \mathrm{~S} \_26$ & 12,97 & 6,54 & 3,98 & HHÖ & 2,290 & $2,314 \mathrm{E}-08$ & 0,9497 \\
\hline \multicolumn{8}{|c|}{ Próbatest elhelyezkedése: T-L/21W } \\
\hline 2B_21 & 25,93 & 13,05 & 5,01 & V & 4,981 & $1,593 \mathrm{E}-13$ & 0,9446 \\
\hline 2B_22 & 25,94 & 13,05 & 5,19 & $\mathrm{~V}$ & 5,192 & $6,125 \mathrm{E}-14$ & 0,9575 \\
\hline 2B_23 & 25,94 & 13,04 & 4,92 & ÖV & 6,722 & $1,340 \mathrm{E}-16$ & 0,7651 \\
\hline 2B_24 & 25,89 & 13,04 & 4,89 & ÖV & 5,341 & $3,755 \mathrm{E}-14$ & 0,9431 \\
\hline 2B_25 & 25,94 & 13,03 & 5,09 & HHÖ & 5,367 & $2,044 \mathrm{E}-11$ & 0,8991 \\
\hline $2 B \_26$ & 25,94 & 13,05 & 4,87 & HHÖ & 5,548 & $3,465 \mathrm{E}-14$ & 0,9560 \\
\hline
\end{tabular}

\section{5. Összefoglalás}

A kapott eredmények és azok kiértékelése alapján az alábbi megállapítások tehetőek.

- Az alkalmazott hegesztési paraméterekkel és körülményekkel megfelelő minőségü hegesztett kötések hozhatók létre autogén elektronsugaras hegesztéssel. 
- A vizsgált S960M acél elektronsugaras hegesztett kötésének fáradásos repedésterjedéssel szembeni ellenállása a vizsgált irányokban (21 és 23) szignifikánsan különböző, a vizsgált S960QL acél esetében ilyen különbség nincs.

- A vizsgált S960QL acél elektronsugaras hegesztett kötései, mindkét vizsgált irányban (21 és 23), lényegesen érzékenyebbek a fáradással terjedő repedések elhelyezkedésére (varrat, összeolvadási vonal, hőhatásövezet), mint a vizsgált S960M acél kötései.

- A kapott eredmények alapján fáradásos repedésterjedési határgörbék határozhatók meg a vizsgált hegesztett kötésekre.

\section{Köszönetnyilvánítás}

Az elektronsugaras hegesztési kísérletek feltételeinek biztositásáért köszönet illeti a Steigerwald Strahltechnik Kft-ét (SST) és magyarországi partnervállalatát az IGM Robotrendszerek Kft-ét.

\section{Irodalom}

[1] Balogh A., Lukács J. és Török I. (szerk.): Hegeszthetőség és a hegesztett kötések tulajdonságai, Miskolci Egyetem, 2015. (ISBN 978-963-358-081)

[2] Blacha S., Weglowski M. S. T., Dymek S. és Kopuscianski M.: Microstructural characterization and mechanical properties of electron beam welded joints of high strength steel grade S690QL, Archives of Metallurgy and Materials, 2016,61:1193-1200.

https://doi.org/10.1515/amm-2016-0198

[3] IIW-1823-07 Recommendations for fatigue design of welded joints and components, International Institute of Welding, 2008

[4] Dobosy, Á.: S690QL és S960M nagyszilárdságú acélok hegesztett kötéseinek fáradásos repedésterjedéssel szembeni ellenállása, Multidiszciplináris Tudományok, 2020,10(1):156-166. https://doi.org/10.35925/j.multi.2020.1.19

[5] Mobark, H. F. H., Lukács, J.: Az alapanyag-hozaganyag párosítás hatása a fáradásos repedésterjedésre nagyszilárdságú acélok és hegesztett kötéseik esetén, Gépgyártás, 2019,58(1-2):76-80.

[6] ASM International: Metals Handbook Volume 6.: Welding, Brazing and Soldering, 1995.

[7] ASTM E 647: Standard test method for measurement of fatigue crack growth rates, ASTM International, 2015.

[8] Paris P. és Erdogan F.: A critical analysis of crack propagation laws Journal of Basic Engineering, Transactions of the ASME, 1963:528-534. https://doi.org/10.1115/1.3656900

[9] Lukács J.: Fatigue crack propagation limit curves for high strength steels based on two-stage relationship, Engineering Failure Analysis, 2019,103:431-442. https://doi.org/10.1016/j.engfailanal.2019.05.012

[10] Lukács J.: Repedést tartalmazó hegesztett kötések megbízhatósága ismétlődő igénybevétel esetén Kandidátusi értekezés, Miskolc-Budapest, 1992. p. 121 